\title{
DAYA ANTI BAKTERI AIR PERASAAN BUAH LEMON (CITRUS LEMON (L) BURM.F.) TERHADAP STREPTOCOCCUS MUTANS DOMINAN KARIES GIGI
}

\author{
R. Ardian Priyambodo, Nurul Hikma Zainal
}

\begin{abstract}
ABSTRAK
Karies gigi merupakan salah satu penyakit infeksi dengan penyebab utama bakteri Streptococcus mutans, untuk menanggulangi terjadinya karies gigi perlu dilakukan suatu alternative pengobatan dengan menggunakan Tanaman Obat Berbahan Alami seperti buah lemon (Citrus limon (L.)Burm.f.) yang memiliki kandungan senyawa aktif yang mempunyai sifat antibakteri. Tujuan penelitian ini adalah untuk mengetahui hasil daya anti bakteri air perasan buah lemon (Citrus Limon (L) Burm.f.) terhadap Streptococcus Mutans Dominan Karies Gigi. Jenis penelitian ini adalah eksperimen laboratorium dengan menggunakan air perasan buah lemon (Citrus Limon (L) Burm.f.) pada konsentrasi $30 \%, 40 \%$, dan 50\%. Berdasarkan hasil penelitian diperoleh zona hambat keseluruhan dari lima media MHA pada konsentrasi 30\% (8,8 mm); 40\% (9,9 mm); 50\% (10,7 mm). Dari hasil penelitian 5 MHA dengan konsentrasi yang lebih tinggi dapat menunjukkan air perasan buah lemon (Citrus Limon (L) Burm.f.) efektif dalam menghambat pertumbuhan bakteri Streptococcusmutans sehingga bersifat bakteriostatik. Air perasaan buah lemon memiliki zona hambat yang lebih besar jika konsentrasi lebih tinggi.
\end{abstract}

Kata kunci: Air perasaan buah lemon terhadap streptococuccus mutans

\section{PENDAHULUAN}

Karies dan penyakit periodontal merupakan penyakit pada rongga mulut yang banyak ditemukan pada masyarakat di Indonesia. Survei Kesehatan Rumah Tangga tahun 2004 menyatakan bahwa, prevalensi karies di Indonesia mencapai 90,06\%. Riset Kesehatan Dasar tahun 2007 menyatakan bahwa indeks DMF-T (Decay Missing FilledTeeth) untuk daerah Sumatera Barat adalah 5.25, yang berarti telah melebihi indeks DMF-T yang telah ditetapkan WHO, yaitu 3, (Susi dkk, 2015).

Karies gigi merupakan masalah utama penyakit gigi yang dapat mengganggu aktivitas manusia sehari-hari. Karies adalah suatu proses kronis yang dimulai dengan larutnya mineral email, sebagai akibat terganggunya keseimbangan antara email dan sekelilingnya yang disebabkan oleh pembentukan asam mikrobial dari makanan, yang menimbulkan destruksi komponen-komponen organik dan akhirnya terjadi kavitasi atau pembentukan lubang (Wardani,2012).

Karies gigi juga dikenal sebagai kerusakan gigi atau rongga, berasal dari bakteri yang menyebabkan demineralisasi jaringan keras (enamel, dentin dan sementum) dan perusakan materi organik gigi dengan produksi asam oleh hidrolisis dari akumulasi sisa-sisa makanan pada permukaan gigi (Hongini 2012).

Saat ini telah dipahami bahwa karies gigi merupakan salah satu penyakit infeksi dengan penyebab multifaktorial. Streptococcus mutans sebagai bakteri penyebab utama terjadinya karies gigi, yang sebelumnya diketahui sebagai bagian dari flora normal dalam rongga mulut yang berperan 
dalam proses fermentasi karbohidrat sehingga menghasilkan asam yang pada akhirnya menyebabkan terjadinya demineralisasi gigi. Streptococcus mutans merupakan bakteri patogen pada mulut yang merupakan agen penyebab utamanya plak, ginggivitis, denture stomatitis dan karies. (Juvensiusdkk, 2014).

Streptococcus mutans termasuk kelompok Streptococcus viridans yang merupakan anggota floralnormal rongga mulut yang memiliki sifat $\alpha$-hemolitik dan komensal oportunistik.Streptococcus mutans merupakan bakteri gram positif, yang mampu menghasilkan asam. Sifat kariogenik bakteri ini dihubungkan dengan berbagai faktor, seperti dextran, dan mampu memproduksi asam pada plak. Bakteri Streptococcus mutans telah diakui di dunia kedokteran gigi sebagai penyebab utama terjadinya karies gigi, sehingga banyak penelitian difokuskan pada spesifikasi bakteri ini.Penelitian-penelitian itu dimaksudkan untuk memperoleh bahan pencegahan penyakit karies gigi yang disebabkan oleh bakteri Streptococcus mutans.

Menanggulangi banyaknya prevalensi penyakit karies di Indonesia maka perlu dilakukan suatu alternatif pengobatan.Usaha pengontrolan plak harus diarahkan pada dua tujuan yaitu membatasi jumlah Streptococcus mutans untuk pencegahan karies serta memelihara kesehatan gigi. Organisasi Kesehatan Dunia (WHO) mencatat bahwa sekitar 75-80\% dari populasi dunia menggunakan Tanaman Obat Berbahan Alami (TOBA) sebagai obat medis karena baik ditoleransi oleh tubuh manusia, dan memiliki efek samping lebih sedikit. Salah satu TOBA yang baik dimanfaatkan adalah buah lemon (Ramadani, 2014).

Pemanfaatan buah lemon sebagai terapi kesehatan dapat digunakan sebagai jus dan infused water. Air perasan buah lemon (Citrus limon (L.) Burm.f.) mengandung banyak senyawa bioaktif seperti flavonoid, karotenoid, limonoid, tannin, dan terpenoid. Senyawa bioaktif yang terkandung dalam lemon masingmasing memiliki sifat antibakteri (Aryani, 2017).

Citrus limon yang biasa dikenal dengan lemon termasuk family Rutaceae, umumnya dibudidayakan di negara-negara Asia Selatan. Lemon kaya akan suplemen gizi yang mengandung karbohidrat, lemak, protein, vitamin seperti thiamine, riboflavin, niacin, asam pantotenat, folat, kolin dan kaya sumber vitamin C. Lemon juga mengandung unsurunsur seperti kalsium, magnesium, kalium dan seng dan sejumlah senyawa fitokimia seperti tannin dan flavonoid.

Kandungan flavonoid pada sitrus memiliki aktivitas biologis yang luas, termasuk sebagai antibakteri, antijamur, antidiabetes, antikanker, dan aktivitas antivirus.

Gluseppe, dkk (2007) melaporkan adanya limonoid pada spesies sitrus, yang dianggap mampu melawan bakteri yang terisolasi secara klinis. Limonoid yang diperoleh dari lemon, menunjukkan aktivitas antibakteri dan antijamur yang baik. Berdasarkan penelitian yang dilakukan Tomotake, dkk zat yang memiliki kemampuan sebagai antibakteri dalam buah jeruk lemon adalah asam sitrat yang merupakan asam organik utama yang terkandung dalam air perasan lemon. Selain itu menurut Zu, dkk kandungan minyak atsiri (monoterpen dan 
sesquiterpen) seperti limonene memiliki aktivitas antibakteri dimana pada buah jeruk lemon juga memiliki kandungan minyak atsiri berupa limonene. Menurut Noghata, dkk tanaman jeruk mengandung komponen flavonoid dimana menurut Cushnie, dkk flavonoid memiliki aktivitas antibakteri.

\section{METODE PENELITIAN}

Penelitian yang dilakukan adalah penelitian eksperimen laboratorium untuk daya anti bakteri air perasan buah lemon (Citrus limon (L.)Burm.f.) terhadap streptococcus mutans dominan karies gigi. Sampel penelitian ini adalah buah lemon yang dijual di pasaran. Penelitian dilaksanakan pada Bulan April sampai dengan Mei 2019. Uji daya anti bakteri air perasan buah lemon (Citrus limon (L.)Burm.f.) terhadap Streptococcus mutans dominan karies gigi di laboratorium mikrobiologi Fakultas Kedokteran UNHAS Makassar.

Alat yang akan digunakan yaitu cawan petri, neraca ouhaos, autoklaf, labu erlenmeyer, tabung reaksi, jangka sorong, inkubator, bunsen, ose bulat, pinset, rak tabung, dan korek api. Bahan yang di gunakan yaitu Streptococcus mutans, buah lemon, aquades steril, Muller Hinton Agar (MHA), spiritus, swab steri, handscone, masker, paper disk, dan spidol.

Pengolahan sampel Buah lemon, buah lemon dicuci, dipotong menjadi dua, kemudian diperas dengan menggunakan alat pemeras jeruk. Untuk mendapatkan air perasan lemon. Air perasan buah lemon yang didapatkan, dibuat larutan sesuai konsentrasi yang akan dipakai. Untuk membuat konsentrasi $30 \% \quad(30 \%: 100 \times 10=3 \mathrm{ml})$ maka dipipet $3 \mathrm{ml}$ air perasan buah lemon ditambahkan $7 \mathrm{ml}$ aquades dimasukkan ke dalam tabung steril, 40\% (40\%:100×10=4ml) maka dipipet $4 \mathrm{ml}$ air perasan buah lemon ditambahkan $6 \mathrm{ml}$ aquades, dan 50\% (50\%:100×10=5ml) maka dipipet $5 \mathrm{ml}$ air perasan buah lemon ditambahkan $5 \mathrm{ml}$ aquades. Untuk uji anti bakteri, disiapkan alat dan bahan yang akan digunakan, media MHA dan koloni Streptococcus mutan, digoreskan suspensi bakteri diatas permukaan media MHA secara merata menggunakan swab steril, diletakkan peper disc yang telah direndam ke dalam air perasan buah lemon $30 \%, 40 \%$, dan $50 \%$, serta kontrol positif, diinkubasi dengan menggunakan inkubator selama 1 × 24 jam pada suhu $37^{\circ} \mathrm{C}$, selanjutnya diukur diameter zona hambat dengan menggunakan jangka sorong. Daya hambat diketahui berdasarkan pengukuran diameter zona inhibisi (zona bening atau daerah jernih tanpa pertumbuhan mikroorganisme) yang terbentuk di sekitar paper disk.

\section{HASIL PENELITIAN}

Telah dilakukan penelitian mengenai daya anti bakteri air perasan buah lemon (Citrus limon (L)Burm.f.) terhadap Streptococcus mutans dominan karies gigi. Penelitian eksperimen ini dilakukan pada bulan April hingga Mei tahun 2019.Dil aboratorium Mikrobiologi Fakultas Kedokteran Universitas Hasanudin Makassar untuk Uji daya hambat. Pada penelitian ini menggunakan bakteri Streptococcus mutans yang diperoleh dari Laboratorium Mikrobiologi Fakultas kedokteran Universitas Hasanudin Makassar. Kemudian 
dari hasil kultur tersebut dilakukan pembuatan

suspensi Streptococcus mutans yang selanjutnya ditanamkan pada media Muller Hinton Agar (MHA). Setelah suspensi Streptococcus mutans ditanamkan pada Media Muller HintonAgar dilakukan Uji aktivitas antimikroba menggunakan metode difusi paper disc dilakukan dengan merendam komponen antimikroba ke paper disc dengan konsentrasi $30 \%, 40 \%$ dengan $50 \%$.

Aktivitas antimikroba air perasan buah lemon (Citrus limon (L)Burm.f.) pada metode difusi paper disc ditunjukkan dengan adanya area bening di sekitar paper disc yang berisi air perasan buah lemon (Citrus limon (L) Burm.f.) pada media agar MHA.

Tabel Hasil uji zona hambat daya anti bakteri air perasan buah lemon (Citrus limon (L)Burm.f.) Terhadap Streptococcus mutans dominan karies gigi.

\begin{tabular}{|c|c|c|c|}
\hline MHA & $\mathbf{3 0 \%}$ & $\mathbf{4 0 \%}$ & $\mathbf{5 0 \%}$ \\
\hline 1 & $9 \mathrm{~mm}$ & $9.6 \mathrm{~mm}$ & $10.2 \mathrm{~mm}$ \\
2 & $8.9 \mathrm{~mm}$ & $10.7 \mathrm{~mm}$ & $10.9 \mathrm{~mm}$ \\
3 & $8.6 \mathrm{~mm}$ & $10.1 \mathrm{~mm}$ & $11.2 \mathrm{~mm}$ \\
4 & $8.7 \mathrm{~mm}$ & $9.3 \mathrm{~mm}$ & $9.9 \mathrm{~mm}$ \\
5 & $9.2 \mathrm{~mm}$ & $9.9 \mathrm{~mm}$ & $11.4 \mathrm{~mm}$ \\
\hline \hline Jumlah & $\mathbf{4 4 . 4} \mathbf{~} \mathbf{m m}$ & $\mathbf{4 9 . 6} \mathbf{~} \mathbf{m}$ & $\mathbf{5 3 . 6} \mathbf{~} \mathbf{m}$ \\
\hline Rerata & $\mathbf{8 . 8} \mathbf{~ m m}$ & $\mathbf{9 . 9} \mathbf{~} \mathbf{m}$ & $\mathbf{1 0 . 7} \mathbf{~} \mathbf{m m}$ \\
\hline
\end{tabular}

Tabel di atas menunjukkan hasil uji zona hambat air perasan buah lemon terhadap bakteri Streptococcus mutans, berdasarkan hasil MHA pertama dengan konsentrasi $30 \%$ sebesar $9 \mathrm{~mm}$; 40\% sebesar $9.6 \mathrm{~mm}$; 50\% sebesar $10.2 \mathrm{~mm}$. MHA kedua dengan konsentrasi $30 \%$ sebesar $8.9 \mathrm{~mm} ; 40 \%$ sebesar $10.7 \mathrm{~mm}$; 50\% sebesar $10.9 \mathrm{~mm}$. MHA ketiga dengan konsentrasi $30 \%$ sebesar $8.6 \mathrm{~mm} ; 40 \%$ sebesar $10.1 \mathrm{~mm}$; 50\% sebesar $11.2 \mathrm{~mm}$. MHA keempat dengan konsentrasi $30 \%$ sebesar $8.7 \mathrm{~mm}$; $40 \%$ sebesar $9.3 \mathrm{~mm}$;
$50 \%$ sebesar $9.9 \mathrm{~mm}$. MHA kelima dengan konsentrasi 30\% sebesar $9.2 \mathrm{~mm} ; 40 \%$ sebesar $9.9 \mathrm{~mm}$; 50\% sebesar $11.4 \mathrm{~mm}$. Dari lima MHA dengan konsentrasi 30\% dijumlah menjadi $44.4 \mathrm{~mm}$; $40 \%$ dijumlah menjadi 49.6 $\mathrm{mm} ; 50 \%$ dijumlah menjadi $53.6 \mathrm{~mm}$. Setelah penjumlahan lima MHA dengan masingmasing konsentrasi dapat dilakukan pembagian konsentrasi dengan lima MHA untuk mendapatkan hasil rerata yang valid yaitu konsentrasi $30 \%$ menjadi $8.8 \mathrm{~mm}$; 40\% menjadi $9.9 \mathrm{~mm}$; 50\% menjadi $10.7 \mathrm{~mm}$. 




\section{Grafik zona hambat Air PerasanBuah Lemon Terhadap Streptococcus mutans}

Grafik zona hambat air perasan buah lemon rerata menunjukkan diameter zona hambat pada $30 \%$ sebesar $8.8 \mathrm{~mm} ; 40 \%$ sebesar $9.9 \mathrm{~mm} ; 50 \%$ sebesar $10.7 \mathrm{~mm}$.

Dari hasil uji zona hambat tabel diatas menunjukkan bahwa konsentrasi $50 \%$ yang paling tinggi ukuran zona hambatnya terhadap koloni jamur Streptococcus mutans.

\section{PEMBAHASAN}

Berdasarkan hasil pengamatan yang dilakukan pada pengujian pada lima MHA yang berbeda memperlihatkan adanya zona hambat yang terbentuk di sekitar paper disc. Rerata diameter zona hambat yang diberi air perasan buah lemon $3 \mathrm{ml}$ dan aquades $7 \mathrm{ml}$ menunjukkan hasil sebesar $8.8 \mathrm{~mm}$; Rerata diameter zona hambat yang diberi air perasan buah lemon $4 \mathrm{ml}$ dan aquades $6 \mathrm{ml}$ menunjukkan hasil sebesar $9.9 \mathrm{~mm}$; Rerata diameter zona hambat yang diberi air perasan buah lemon $5 \mathrm{ml}$ dan aquades $5 \mathrm{ml}$ menunjukkan hasil sebesar $10.7 \mathrm{~mm}$.

Dari hasil penelitian yang diperoleh menunjukkan bahwa uji daya hambat air perasanbuah lemon terhadap Streptococcus mutan yaitu dimana konsentrasi 30\%, 40\%, dan $50 \%$ sudah memperlihatkan adanya zona hambat, diketahui bahwa pada konsentrasi tersebut mempunyai zona hambat yang semakin meluas sesuai dengan semakin besar konsentrasi air perasan buah lemon (Citrus limon (L)Burm.f.) yang berarti semakin tinggi konsentrasi maka semakin baik dalam menghambat bakteri Streptococcus mutans.

Pada penelitian ini digunakan air perasan buah lemon (Citrus limon (L)Burm.f.). Pada pembuatan konsentrasi digunakan air perasan buah dan aquades dimaksudkan agar didapatkan suatu senyawa terkandung dalam air perasanbuah lemon yang diduga dapat berperan sebagai antimikroba.

Zona hambat yang terbentuk di sekitar paper disc diberi air perasan buah lemon tergolong sedang, menunjukkan kemampuan zat yang terkandung dalam kandungan yang terdapat pada air perasan buah lemon dalam menghambat pertumbuhan Streptococcus mutans. Lebar diameter zona hambat yang terbentuk di sekitar paper disc dapat dijadikan parameter untuk melihat kekuatan senyawa bioaktif yang terkandung dalam air perasan 
buah lemon. Semakin besar zona hambat yang terbentuk mengindikasikan semakin kuatnya senyawa bioaktif menghambat pertumbuhan Streptococcus mutans. Semakin kecil zona hambat yang terbentuk, maka semakin kecil kemampuan senyawa bioaktif dalam menghambat pertumbuhan Streptococcus mutans.

\section{KESIMPULAN}

Dari hasil penelitian tentang daya anti bakteri air perasan buah lemon (Citrus limon) terhadap bakteri Streptococcus mutans dominan karies gigi, maka dapat disimpulkan bahwa: Semakin besar konsentrasi air perasan buah lemon yang berarti semakin tinggi konsentrasi air perasan buah lemon maka semakin baik dalam menghambat bakteri streptococcus mutans.

\section{SARAN}

Perlu dilakukan penelitian lebih lanjut mengenai khasiat farmakologis zat-zat aktif yang terkandung di dalam air perasan buah lemon terhadap bakteri lainnya, serta sifat toksisitas khususnya pada gigi dan mulut. Selain itu, perlu dilakukan penelitian lebih lanjut mengenai konsentrasi air perasan buah lemon serta proses konsentrasi yang lebih tinggi.

\section{DAFTAR PUSTAKA}

Amiruddin. S. A. 2014. Daya Hambat Ekstrak Bawang Putih (Allium Sativum) Terhadap Pertumbuhan Streptococcus mutans Secara In Vitro. Universitas Hasanudin kedokteran gigi: Makassar.

Ariani,Inggrit Devita.2017. Gambaran Air Perasan Jeruk Lemon (Citrus Limon (L) Brum.f.) Terhadap Pertumbuhan
Bakteri Staphylococcus Aureus. Karya Tulis IImiah. STIKES Insan Cendekia Medika. Jombang.

Batubara A N,2017. Efek Air Perasan Buah Jeruk Lemon (Citrus Limon) Terhadap Laju Aliran, Nilai $\mathrm{Ph}$ Saliva dan Jumlah Koloni Sthapylococcus Aureus. Karya Tulis Ilmiah. fakultas Kedokteran Gigi Universitas Sumatra Utara: Medan.

Berlian, Z, Fatiqin, A, Agustina, E. 2016. Penggunaan Perasan Jeruk Nipis (Citrus Aurantifolia) dalam Menghambat Bakteri Escherichia Coli Pada Bahan Pangan. Jurnal Bioilmi vol. 2 no. 1 hal. 55-56.

Berti.L.P.2015. Daya Anti Bakteri Air Perasan Buah Lemon (Citrus Limon (L)Brum.F.) Terhadap Porphyromonas Gingivalis Dominan Periodontitis. Karya Tulis Ilmiah. Fakultas Kedokteran Gigi Universitas Muhammadiah: Surakarta.

Ferry. A. B, 2014. Hubungan Pengetahuan Kesehatan Gigi Terhadap Dmf-T \& Ohis Pada Anak Usia 10-12 Tahun di Makassar. Fakultas Kedokteran Gigi Unhas:Makassar.

Hongini.s.y.2012. Kesehatan Gigi DAN Mulut Buku Dental Terminology: Bandung.

Hudri, 2014. Uji Efektifitas Ekstrak Madu Multifaktora Dalam Menghambat Pertumbuhan Bakteri Salmonella typi. Universitas Islam Negri Syarif Hidayatullah: Jakarta.

Inayatullah.S,2012. Efek Ekstrak Daun Sirih Hijau (Piper Betle L.) Terhadap Pertumbuhan Bakteri Staphylococcus aureus. Fakultas Kedokteran dan IImu Universitas Islam Negeri Syarif Hidayatullah: Jakarta.

Juvensius.dkk, 2014. Uji Efektifitas Ekstrak Bunga Cengkeh Terhadap Bakteri Streptococcus Mutans Secara In vitro. Fakultas kedokteran Universitas Sam Ratulangi: Manado.

Kusuma.R.B.B. E,2010. Pengaruh Daya Antibakteri Ekstrak Daun Sirih (Piper betle L.) Terhadap Streptococcus mutans. Fakultas Kedokteran Universitas Sebelas Maret: Surakarta.

Maharani,2012. Efek Hambat Berbagai Pasta Gigi Terhadap Streptococcus Mutans. Fakultas Kedokteran dan IImu Kesehatan UIN Syarif Hidayatullah: Jakarta. 
Marwanto,2014. Definisi Jeruk Lemon. http://digilib.unimus.ac.id/files/disk1/16 0 . Diakses 24/01/2019.

Muaris, Hindah. 2014. Khasiat Lemon Untuk Kestabilan Kesehatan. Gramedia Pustaka Utama.

Nisa Z N. 2018. Daya Hambat Air Perasan Jeruk Lemon (Citrus Limon (L.)Burm.f.) Pada Pertumbuhan Bakteri Escherichia Coli. Karya Tulis IImiah. Sekolah tinggi IImu Kesehatan Insan Cendekia Medika Jombang.

Nizhar, 2012. Kandungan Kimia Buah Lemon. http://digilib.unimus.ac.id/files/disk1/16 0 Diakses 24/01/2019.

Nugraha. A. W. 2008. Streptococcus mutans. Fakultas Farmasi UCD:Yogyakarta.

Nurlaely.E,2016. Uji Efektivitas Air Perasan Jeruk Lemon (Citrus Limon (L.)Burm.f.) Terhadap Bakteri Staphylococcus aureus, Sekolah Tinggi Ilmu Kesehatan Muhammadiyah:Ciamis.

Pinatih, P.I. 2014. Karies Pada Anak yang Menyikat Gigi di Sekolah. Universitas Mahasaraswati: Denpasar

Taringan R.2016 Karies Gigi Buku Kedokteran :J akarta.
Ramadahani. A. F. 2013. Potensi Anti Mikroba Kayu Siwak (Salvadora Persica Wall) Terhadap Streptococcus aureus dan Pseudomonas aerruginosa Serta Aplikasi Pada Bakso Daging. Fakultas Teknologi Pertanian Bogor: Bogor.

Riyandena.G,2010. Dental Caries/ Karies Gigi/ Tooth Decay

Susi.dkk, 2015. Peredaan Daya Hambat Pasta Gigi Berbahan Herbal Terhadap Pertumbuhan Streptococcus mutans. Fakultas Kedokteran Gigi Andalas: Padang.

Wardani. P. A. 2012. Pengaruh Pemberian Larutan Ekstrak Siak (Salvadora persica) Pada Berbagai Konsentrasi Terhadap Pertumbuhan Streptococcus mutans. Fakultas Kedokteran Universitas Dipenogoro: Semarang.

Wasitaningrum.I.D.A,2009. Uji Resistensi Bakteri Staphylocccus aureus dan Escherichia coli dari isolat susu sapi segar terhadap beberapa antibiotik. Fakultas Farmasi Universitas Muhammadiyah: Surakarta. 